\title{
Lignin: Renewable Raw Material for Adhesive
}

\author{
Ravindra V. Gadhave*, Shrray Srivastava, Prakash A. Mahanwar, Pradeep T. Gadekar \\ Department of Polymer and Surface Engineering, Institute of Chemical Technology, Mumbai, India \\ Email: *ravi.gadhave3@gmail.com
}

How to cite this paper: Gadhave, R.V., Srivastava, S., Mahanwar, P.A. and Gadekar, P.T. (2019) Lignin: Renewable Raw Material for Adhesive. Open Journal of Polymer Chemistry, 9, 27-38.

https://doi.org/10.4236/ojpchem.2019.92003

Received: January 30, 2019

Accepted: May 5, 2019

Published: May 8, 2019

Copyright $\odot 2019$ by author(s) and Scientific Research Publishing Inc. This work is licensed under the Creative Commons Attribution International License (CC BY 4.0).

http://creativecommons.org/licenses/by/4.0/

\begin{abstract}
Biobased raw material like lignin used during manufacturing of wood and wood composite adhesive have been used extensively to replaced petro-chemical based adhesive because of their easy availability, low cost and biodegradability. Bio-based resources, such as lignin which is an abundant, constitute a rich source of hydroxyl functionality which is being considered as reactive raw material for the production of "adhesives". Lignin is mainly used for production of wood and wood composite adhesives by blending with soy protein, grafting with another polymer and reacting with isocynates. In this review, lignin as suitable alternative raw material to conventional petroleum sourced materials used as a raw material for adhesives is discussed.
\end{abstract}

\section{Keywords}

Polyol, Lignin, Wood, Adhesive, Biopolymer

\section{Introduction}

Most polymeric coatings and adhesives are generally based on fossil feedstocks. However, increasing oil prices and global warming demands a change from fossil feedstocks to renewable resources. Recently, researchers are increasingly devoting their efforts to the possible use of renewable feedstock as raw materials for the production of monomers and their polymeric coatings and adhesives. Renewable resources like vegetable oils based fatty acids, proteins and animal fats are readily available. There have been many studies of polymers based on vegetable oils, such as vinyl polymers, epoxy resins, alkyd resins, polyamides, and polyurethanes [1]. There has been a more research interest in the development of biobased wood adhesives from renewable resources. Various biomass resources such as lignin, starch, plant proteins, tannin, bark, and vegetable oils have been used as a renewable feedstock to synthesize bio-based adhesives [2]. Due to increasing economic and environmental issues, lingo-cellulosic biomass 
an abundant renewable resource becomes an ideal alternative to non-renewable petroleum resources. Lignins obtained in industry, however, are technical lignins, such consisting soda lignin, kraft lignin, lignin sulfonate, organosolv lignin, steam explosion lignin and enzymatic hydrolysis lignin. These are the byproducts of certain bio refinery processes [3]. Lignin is an amorphous natural polymeric material that is based on phenylpropane derivate and one of the most abundant materials and renewable resources on earth. It is well accepted that lignin is a phenolic polymer derived primarily from three hydroxycinnamyl alcohols or monolignols by free radical generation followed by chemical coupling process. The hydrocycinnamyls are p-coumaryl alcohol, coniferyl alcohol and sinapyl alcohol. Lignin is never defined as a class of phenolic natural polymers with broad compositions and a variety of linkages between units [4]. Lignin has been attracting interest as a novel eco-friendly material because of its physical properties and favourable degradation characteristics. By transforming forest and agricultural feedstocks, new renewable, biodegradable, and biocompatible materials are being produced [5]. Lignin acts as a reactive component, and the active functional groups in lignin are further utilized for biocompatible materials [6].

\section{Lignin: Use as an Adhesive}

Most of the adhesive components were derived from petroleum, which are increasingly more expensive. Another problem is that the cured adhesives within panel products limit the reuse options of the discarded boards and production residuals. Both economical and health benefits could thus be obtained from synthetic resin-free production processes.

\subsection{Blending of Lignin with Other Polymers}

Soy protein has great potential as sustainable biobased wood adhesive but they have low moisture resistance. Lignin has more moisture resistance than soy protein. Bio based adhesive derived from blend of Soy protein and lignin could improve moisture resistance as well as economical. The wet strength of soy protein adhesive increased as lignin particle size decreased [7] [8] [9] [10] [11]. The lignin amine modified soy adhesive exhibited excellent water resistance and high dry and wet shear strengths for plywood. Because of the lignin used in this study largely retained its native highly branched structure, it is not soluble in water and most of organic solvents. However the preparation of partially de-polymerized lignin (PDL) increase solubility in solvents and hence increased accessibility of the hydroxyl groups for reactions. Comparing to PDL amine, the amine based on not de-polymerized lignin could more greatly enhance the adhesion strength and water resistance of soy protein based adhesives reaction is shown in Figure 1 [12]-[18].

Starch based adhesives are susceptible to colonization by a variety of microbes including molds and fungi which can decrease the effective lifetime of the 


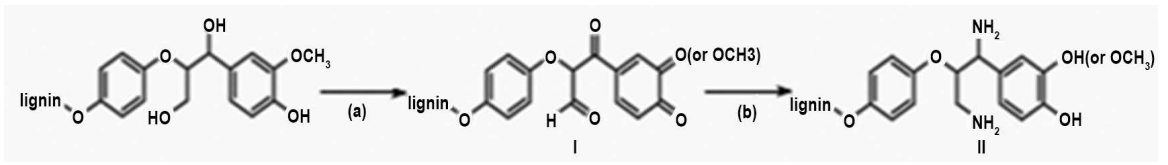

Figure 1. Synthesis route for preparation of lignin amine.

adhesive and the product into which lignin is incorporated [19]-[24]. The good compatibility and intermolecular interaction shown by PVA and lignin blend may contribute to sustainability and reduction in the environmental impact associated with disposal of oil-based polymers [25]-[33]. The nanokraft lignin particles when used with polyvinyl alcohol (PVA) increased the thermal stability of nano lignin/PVA blends more effectively compared to the original lignin/PVA blends [34]. In Urea formaldehyde resins, Decrease in formaldehyde release and increase in water resistance was observed by incorporation of lignin [35]-[44].

\subsection{Lignin with Different Cross-Linkers}

Corn stalk lignin was used to react with non-volatile and non-toxic glyoxal under the catalysis of a sodium hydroxide solution, and a wood adhesive based on glyoxal modified corn stalk lignin was prepared. Lignin-based environmental wood adhesives were prepared by mixing modified lignin and epichlorohydrin $(\mathrm{ECH})$, and the dry strength of plywood reached $1.58 \mathrm{MPa}$. The mechanical strength and water resistance of plywood was improved significantly by mixing some aqueous emulsion into lignin-based adhesives [45]-[50]. The hydrogen in phenolic group of lignin interacts with functional group of protein forming a cross-linked structure thereby increasing the tensile strength, thermal stability and young's modulus while decreasing water absorption of protein [51] [52] [53].

\subsection{Lignin as Reactive Raw Material}

Grafting vinyl acetate onto lignin, the mechanical and thermal properties of lignin were enhanced and also made better material with more desirable properties. The hydrophobic character of lignin improved by grafting reducing moisture absorption [54] [55] [56] [57] [58] (Figure 2).

The hydroxyl group of lignin reacts with isocyanate group to form polyurethane adhesive A series of waterborne polyurethane (WBPU)/modified lignin amine (MLA) adhesives was prepared using MLA as a chain extender by a prepolymer mixing process [59] [60] [61]. The addition of lignin into the formulated PF resin improved the thermal properties and varied the flow behavior of PF resin from Newtonian to Pseudo plastic type. The phenolic nature of lignin makes it prone to replace phenol with lignin derivatives in PF resins to formulate wood composite adhesives suitable for plywood, particle board and other similar kind of composites, replacing current synthetic PF resins which are based on petrochemical, non-renewable sources [62]-[72]. There is a growing demand to develop renewable aromatic compounds to replace the petroleum based Bis-phenol A. Here lignin can be used to develop Renewable epoxy networks economically with low ecological harm as shown in Figure 3 [73]-[78]. 


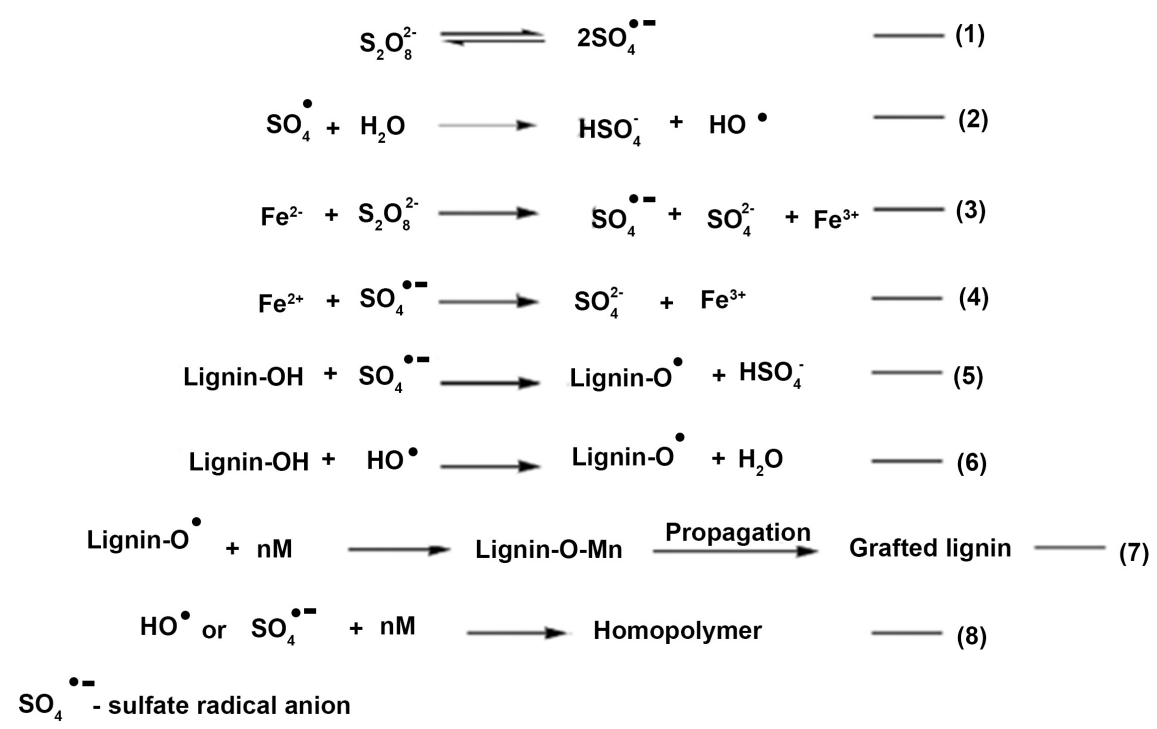

Figure 2. Grafting of monomer onto lignin.

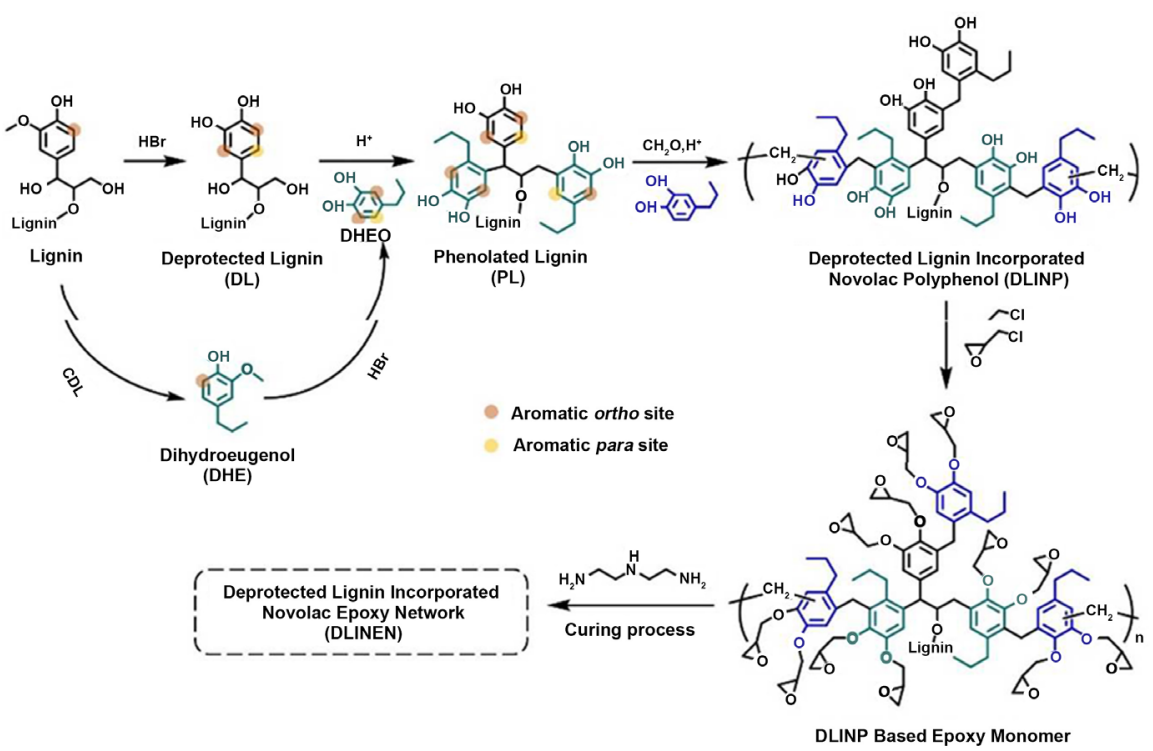

Figure 3. Lignin incorporated Epoxy network.

Controlled modification of lignin is done to form maleimide lignin derivative and were reacted through an extremely fast thiolene "click" polymerization with thiol containing linkers. Increasing the thiol linker functionality from 2 to 4 results in more crosslinked material [79]. Lignocellulosic ethanol residue(ER), as the by-product of lignocelluloses ethanol production, is rich in activated lignin and usually treated as waste. The ER was used as a renewable and valuable resource to partially replace phenol in the range of $10 \%-70 \%$ to prepare lignin-phenol formaldehyde adhesive [80] [81]. Lignin-phenol-formaldehyde resin adhesives with $10 \%-60 \%$ substitution rates and low residual toxicity were successfully synthesized. These results indicate that the lignin-phenol-formaldehyde resin adhesives synthesized using the designed formulation could effectively 
control formaldehyde emissions without any significant drop in the bonding strength of the bonded plywood [82].

Polyurethanes are a heterogeneous family of polymers that include in its backbone the urethane group (-NH-CO-O), also known as carbamate group. The urethane linkages generally result from the reaction between an isocyanate group and a hydroxyl function. For polyurethane synthesis purposes, lignin can act as a source of reactive hydroxyl site; it contains within its structure, both aliphatic and aromatic hydroxyl groups can potentially act as reactive sites for isocyanate groups to form urethane linkages as shown in Figure 4.

\section{Conclusion}

To conclude, lignin has shown to be a potential raw material for adhesive manufacturing, looks promising both as inert filler and as a reactive component. The depletion of natural sources, increasing environmental problems and tightening regulations have not only directed but also pushed adhesive manufacturers to look for more sustainable and renewable solutions. Incorporation of lignin, one of the most widely available natural polymers, into our adhesives is definitely a step in this direction. The feasibility studies and preliminary results discussed in this review show a positive sign for adhesive manufacturers looking for low cost, eco-friendly alternatives for traditional materials. Even though as a limited replacement to petroleum based materials, the discussion of various studies and research articles show a path to reduce our dependency on naturally expensive and depleting sources.

\section{Futuristic Approach}

Lignin is one of the most common naturally occurring renewable materials. Millions of tones of lignin is incinerated as waste each year. The current trends

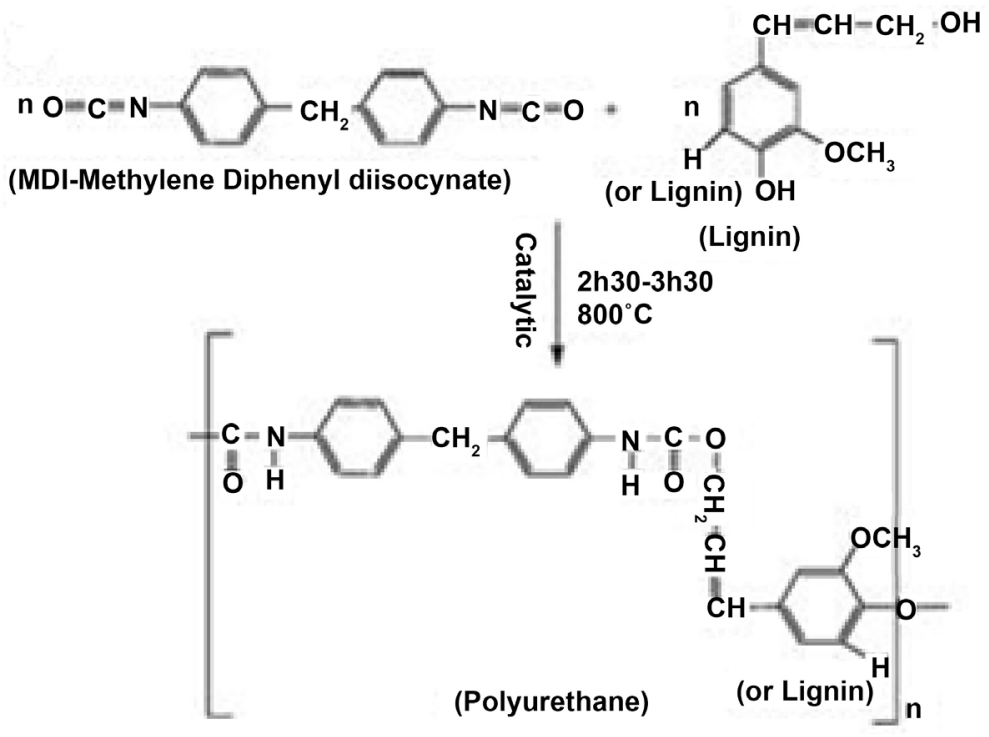

Figure 4. Reaction between lignin and isocyanate. 
related to use of lignin, as discussed in this review, show that lignin has various advantages when incorporated in adhesives. The high phenolic content in lignin adds fire retardancy while the components derived from de-polymerized lignin can replace synthetic phenols in phenol-formaldehyde adhesives. From epoxies, phenol-formaldehyde, polyurethanes to poly vinyl acetate based glues; lignin can be incorporated in various systems across chemistries either as filler or as a reactive starting material.

The future developments with regards to lignin's role in adhesives seem to be in replacing and also improving performance of traditional adhesives. It can be used to fulfill many roles depending on the desired properties and can be suitably modified to optimize performance. The low cost, sustainable sourcing and biodegradability of lignin will help adhesive manufacturers looking for ecofriendly and greener alternatives to traditional raw-material sources. Further exploration on characterization, modifications and incorporation of lignin in various adhesive systems is required to get more benefits from incorporating lignin in the system and get further acceptance by chemical manufacturers.

\section{Conflicts of Interest}

The authors declare no conflicts of interest regarding the publication of this paper.

\section{References}

[1] Rahman, M.M., Zahir, M.H. and Kim, H.D. (2016) Synthesis and Properties of Waterborne Polyurethane (WBPU)/Modified Lignin Amine (MLA) Adhesive: A Promising Adhesive Material. Polymers, 8, 318. https://doi.org/10.3390/polym8090318

[2] Zhang, W., Ma, Y., Wang, C., Li, S., Zhang, M. and Chu, F. (2013) Preparation and Properties of Lignin-Phenol-Formaldehyde Resins Based on Different Biorefinery Residues of Agricultural Biomass. Industrial Crops and Products, 43, 326-333. https://doi.org/10.1016/j.indcrop.2012.07.037

[3] Wang, S., Yu, Y. and Di, M. (2018) Green Modification of Corn Stalk Lignin and Preparation of Environmentally Friendly Lignin-Based Wood Adhesive. Polymers, 10, 631. https://doi.org/10.3390/polym10060631

[4] Hu, L., Pan, H., Zhou, Y. and Zhang, M. (2011) Methods to Improve Lignins Reactivity as a Phenol Substitute and as Replacement for Other Phenolic Compounds: A Brief Review. BioResources, 6, 3515-3525.

[5] Todorciuc, T., Capraru, A.M., Kratochvilova, I. and Popa, V.I. (2009) Characterization of Non-Wood Lignin and Its Hydoxymethyl a Ted Derivatives by Spectroscopy and Self-Assembling Investigations. Cellulose Chemistry and Technology, 43, 399-408.

[6] El-Mansouri, N.E., Yuan, Q. and Huang, F. (2011) Characterization of Alkaline Lignins for Use in Phenol-Formaldehyde and Epoxy Resins. Bioresource, 6, $2647-$ 2662.

[7] Pradyawong, S., Qi, G., Li, N., Sun, X.-S. and Wang, D. (2017) Adhesion Properties of Soy Protein Adhesives Enhanced by Biomass Lignin. International Journal of Adhesion and Adhesives, 75, 66-73. https://doi.org/10.1016/j.ijadhadh.2017.02.017

[8] Luo, J., Luo, J., Yuan, C., Zhang, W., Li, J., Gao, Q. and Chen, H. (2015) An 
Eco-Friendly Wood Adhesive from Soy Protein and Lignin: Performance Properties. RSC Advances, 5, 100849-100855. https://doi.org/10.1039/C5RA19232C

[9] Xiao, Z., Li, Y., Wu, X., Qi, G., Li, N., Zhang, K., Wang, D. and Sun, X.S. (2013) Utilization of Sorghum Lignin to Improve Adhesion Strength of Soy Protein Adhesives on Wood Veneer. Industrial Crops and Products, 50, 501-509. https://doi.org/10.1016/j.indcrop.2013.07.057

[10] Schorr, D., Diouf, P.N. and Stevanovic, T. (2014) Evaluation of Industrial Lignins for Biocomposites Production. Industrial Crops and Products, 52, 65-73. https://doi.org/10.1016/j.indcrop.2013.10.014

[11] Ibrahim, V., Mamo, G., Gustafsson, P.J. and Hatti-Kaul, R. (2013) Production and Properties of Adhesives Formulated from Laccase Modified Kraft Lignin. Industrial Crops and Products, 45, 343-348. https://doi.org/10.1016/j.indcrop.2012.12.051

[12] Xin, J., Zhang, P., Wolcott, M.P., Zhang, J., Hiscox, W.C. and Zhang, X. (2017) A Novel and Formaldehyde-Free Preparation Method for Lignin Amine and Its Enhancement for Soy Protein Adhesive. Journal of Polymers and the Environment, 25, 599-605. https://doi.org/10.1007/s10924-016-0844-x

[13] Hoftiezer, H.W., Watts, D.J. and Takahashi, A (1984) Cationic Reaction Product of Kraft Lignin with Aldehyde and Polyamine. US Patent No. 4455257.

[14] Dong, H., Peng, W. and Lewis, L.N. (2013) Formaldehyde-Free Ligninamine Coagulants for Coagulating Suspended Materials in Water Stream. US Patent No. 9181405.

[15] Zhu, X., Wang, D., Li, N. and Sun, X. (2017) Bio-Based Wood Adhesive from Camelina Protein (a Biodiesel Residue) and Depolymerized Lignin with Improved Water Resistance. ACS Omega, 2, 7996-8004. https://doi.org/10.1021/acsomega.7b01093

[16] Xu, C., Arancon, R.A.D., Labidi, J. and Luque, R. (2014) Lignin Depolymerisation Strategies: Towards Valuable Chemicals and Fuels. Chemical Society Reviews, 43, 7485-7500. https://doi.org/10.1039/C4CS00235K

[17] Aracri, E., Díaz Blanco, C. and Tzanov, T. (2014) An Enzymatic Approach to Develop a Lignin-Based Adhesive for Wool Floor Coverings. Green Chemistry, 16, 2597-2603. https://doi.org/10.1039/c4gc00063c

[18] Liu, Y., Hu, T., Wu, Z., Zeng, G., Huang, D., Shen, Y., He, X., Lai, M. and He, Y. (2014) Study on Biodegradation Process of Lignin by FTIR and DSC. Environmental Science and Pollution Research, 21, 14004-14013. https://doi.org/10.1007/s11356-014-3342-5

[19] Turunen, M., Alvila, L., Pakkanen, T.T. and Rainio, J. (2003) Modification of Phenol-Formaldehyde Resol Resins by Lignin, Starch, and Urea. Journal of Applied Polymer Science, 88, 582-588. https://doi.org/10.1002/app.11776

[20] Baumberger, S., Monties, B. and Valle, G.D. (1998) Use of Kraft Lignin as Filler for Starch Films. Polymer Degradation and Stability, 59, 273-277. https://doi.org/10.1016/S0141-3910(97)00193-6

[21] Julinova, M. Kupec, J., Alexy, P., Hoffmann, J., Sedlarik, V., Vojtek, T., Chromcakova, J. and Bugaj, P. (2010) Lignin and Starch as Potential Inductors for Biodegradation of Films Based Onpoly(Vinyl Alcohol) and Protein Hydrolysate. Polymer Degradation and Stability, 95, 225-233. https://doi.org/10.1016/j.polymdegradstab.2009.10.008

[22] Kaewtatip, K. and Thongmee, J. (2013) Effect of Kraft Lignin and Esterified Lignin on the Properties of Thermoplastic Starch. Materials \& Design, 49, 701-704. https://doi.org/10.1016/j.matdes.2013.02.010 
[23] Shi, R. and Li, B. (2016) Synthesis and Characterization of Cross-Linked Starch/ Lignin Film. Starch, 68, 1224-1232. https://doi.org/10.1002/star.201500331

[24] Sarwono, A., Man, Z., Bustam, M.A., Subbarao, D., Idris, A., Muhammad, N., Khan, A.S. and Ullah, Z. (2017) Swelling Mechanism of Urea Cross linked Starch-Lignin Films in Water. Environmental Technology, 19, 1-31.

[25] Lora, J. and Glasser, W. (2002) Recent Industrial Applications of Lignin: A Sustainable Alternative to Nonrenewable Materials. Journal of Polymers and the Environment, 10, 39-48. https://doi.org/10.1023/A:1021070006895

[26] Korbag, I. and Mohamed Saleh, S. (2015) Studies on Mechanical and Biodegradability Properties of PVA/ Lignin Blend Films. International Journal of Environmental Studies, 73, 18-24. https://doi.org/10.1080/00207233.2015.1082249

[27] Corradini, E., Pineda, E.A.G. and Hechenleitner, A.A.W. (1999) Lignin-Poly (Vinyl Alcohol) Blends Studied by Thermal Analysis. Polymer Degradation and Stability, 66, 199-208. https://doi.org/10.1016/S0141-3910(99)00066-X

[28] Mao, J.Z., Zhang, L.M. and Xu, F. (2012) Fractional and Structural Characterization of Alkaline Lignins from Carexmeyeriana Kunth. Cellulose Chemistry and Technology, 46, 193-205.

[29] Tejado, A., Peña, C., Labidi, J., Echeverria, J.M. and Mondragon, I. (2007) Physico-Chemical Characterization of Lignins from Different Sources for Use in Phenol-Formaldehyde Resin Synthesis. Bioresource Technology, 98, 1655-1663. https://doi.org/10.1016/j.biortech.2006.05.042

[30] Minu, K., Jiby, K.K. and Kishore, V.V.N. (2012) Isolation and Purification of Lignin and Silica from the Black Liquor Generated during the Production of Bioethanol from Rice Straw. Biomass and Bioenergy, 39, 210-217. https://doi.org/10.1016/j.biombioe.2012.01.007

[31] Su, L., Xing, Z., Wang, D., Xu, G., Ren, S. and Fang, G. (2013) Mechanical Properties Research and Structural Characterization of Alkali Lignin/Poly (Vinyl Alcohol) Reaction Films. BioResources, 8, 3532-3543. https://doi.org/10.15376/biores.8.3.3532-3543

[32] Kubo, S. and Kadla, J.F. (2003) The formation of Strong Intermolecular Interactions in Immiscible Blends of Poly(Vinyl Alcohol) (PVA) and Lignin. Biomacromolecules, 4, 561-567. https://doi.org/10.1021/bm025727p

[33] Korbag, I. and Saleh, S.M. (2016) Studies on the Formation of Intermolecular Interactions and Structural Characterization of Polyvinyl Alcohol/Lignin Film. International Journal of Environmental Studies, 73, 226-235. https://doi.org/10.1080/00207233.2016.1143700

[34] Pu, Y., Sun, Q., Pan, S., Zhu, S.-Y., Deng, Y. and Ragauskas, A.J. (2014) High Shear Homogenization of Lignin to Nanolignin and Thermal Stability of NanoligninPolyvinyl Alcohol Blends. ChemSusChem, 7, 3513-3520.

[35] Younesi-Kordkheili, H., KazemiNajafi, S., Behrooz, R. and Pizzi, A. (2015) Improving Urea Formaldehyde Resin Properties by Glyoxalated Soda Bagasse Lignin. European Journal of Wood and Wood Products, 73, 77-85. https://doi.org/10.1007/s00107-014-0850-4

[36] Alam Khan, M., Ashraf, S.M. and Malhorta, V.P. (2004) Development and Characterization of a Wood Adhesive Using Bagasse Lignin. International Journal of Adhesion and Adhesives, 24, 485-493. https://doi.org/10.1016/j.ijadhadh.2004.01.003

[37] Cetin, N. and Ozmen, N. (2003) Studies on Lignin Based Adhesives for Particleboard Panels. Turkish Journal of Agriculture and Forestry, 27, 183-189. 
[38] El-Mansouri, N.E. and Salvado, J. (2006) Structural Characterization of Technical Lignins for the Production of Adhesives: Application to Lignosulfonate, Kraft, Soda-Anthraquinone, Organosolv and Ethanol Process Lignins. Industrial Crops and Products, 24, 8-16. https://doi.org/10.1016/j.indcrop.2005.10.002

[39] El-Mansouri, N.E., Pizzi, A. and Salvado, J. (2007) Lignin-Based Wood Panel Adhesives without Formaldehyde. Holz als Roh-und Werkstoff, 65, 65-70. https://doi.org/10.1007/s00107-006-0130-z

[40] Pizzi, A. (2006) Recent Developments in Eco-Efficient Bio-Based Adhesives for Wood Bonding: Opportunities and Issues. Journal of Adhesion Science and Technology, 20, 829-846. https://doi.org/10.1163/156856106777638635

[41] Mansouri, H.R., Navarrete, P., Pizzi, A., Tapin-lingua, S., Benjelloun-Mlayah, B., Pasch, H. and Rigolet, S. (2011) Synthetic-Resin-Free Wood Panel Adhesives from Mixed Low Molecular Mass Lignin and Tannin. European Journal of Wood and Wood Products, 69, 221-229. https://doi.org/10.1007/s00107-010-0423-0

[42] Navarrete, P., Pizzi, A., Pasch, H. and Delmotte, L. (2012) Study on Lignin-Glyoxal Reaction by MALDI-TOF and CP-MAS 13C NMR. Journal of Adhesion Science and Technology, 26, 1069-1082.

[43] Navarrete, P., Pizzi, A., Rode, K., Vignali, M. and Pasch, H. (2013) MALDI-TOF Study of Oligomers Distribution in Stability-Durable Spraydried Glyoxalated Lignin for Wood Adhesives. Journal of Adhesion Science and Technology, 27, 586-597. https://doi.org/10.1080/01694243.2012.690618

[44] Sevastyanova, Q., Qin, W. and Kadla, J.F. (2010) Effect of Nanofillers as Reinforcement Agents for Lignin Composite Fibers. Journal of Applied Polymer Science, 117, 2877-2881. https://doi.org/10.1002/app.32198

[45] Zhang, X., Zhu, Y., Yu, Y. and Song, J. (2017) Improve Performance of Soy FlourBased Adhesive with a Lignin-Based Resin. Polymers, 9, 261. https://doi.org/10.3390/polym9070261

[46] Ghaffar, S.H. and Fan, M. (2014) Lignin in Straw and Its Applications as an Adhesive. International Journal of Adhesion and Adhesives, 48, 92-101. https://doi.org/10.1016/j.ijadhadh.2013.09.001

[47] Yang, S., Wu, J.-Q., Zhang, Y., Yuan, T.-Q. and Sun, R.-C. (2015) Preparation of Lignin-Phenol-Formaldehyde Resin Adhesive Based on Active Sites of Technical Lignin. Journal of Biobased Materials and Bioenergy, 9, 266-272.

https://doi.org/10.1166/jbmb.2015.1514

[48] Calvo-Flores, F.G. and Dobado, J.A. (2010) Lignin as Renewable Raw Material. ChemSusChem, 3, 1227-1235. https://doi.org/10.1002/cssc.201000157

[49] Ghorbani, M., Liebner, F., Herwijnen, H.W.G.V., Pfungen, L., Krahofer, M. and Budjav, E. (2016) Lignin Phenol Formaldehyde Resins: The Impact of Lignin Type on Adhesive Properties. BioResources, 29, 6727-6741. https://doi.org/10.15376/biores.11.3.6727-6741

[50] Wang, S., Lai, Y.-Y., Yu, Y.-L., Yao, Z.-W. and Di, M.-W. (2017) Hydroxyethylated Modification of Corn Stalk Lignin. ChemBioEng Reviews, 9, 24-28.

[51] Cong, F., Diehl, B.G., Hill, J.L., Brown, N.R. and Tien, M. (2013) Covalent Bond Formation between Amino Acids and Lignin: Cross-Coupling between Proteins and Lignin. Phytochemistry, 96, 449-456.

https://doi.org/10.1016/j.phytochem.2013.09.012

[52] Hatakeyama, H., Tsujimoto, Y., Zarubin, M.J., Krutov, S.M. and Hatakeyama, T. (2010) Thermal Decomposition and Glass Transition of Industrial Hydrolysis Lignin. Journal of Thermal Analysis and Calorimetry, 101, 289-295. 
https://doi.org/10.1007/s10973-010-0698-8

[53] Qi, G.-Y. and Sun, X.-S. (2011) Soy Protein Adhesive Blends with Synthetic Latex on Wood Veneer. Journal of the American Oil Chemists' Society, 88, 271-281. https://doi.org/10.1007/s11746-010-1666-y

[54] Panesar, S.S., Jacob, S., Misra, M. and Mohanty, A.K. (2013) Functionalization of Lignin: Fundamental Studies on Aqueous Graft Copolymerization with Vinyl Acetate. Industrial Crops and Products, 46, 191-196. https://doi.org/10.1016/j.indcrop.2012.12.031

[55] Chen, M.-J., Gunnells, D.W., Gardner, D.J., Milstein, O., Gersonde, R., Feine, H.J., Hüttermann, A., Frund, R., Lüdemann, H.D. and Meister, J.J. (1996) Graft Copolymers of Lignin with 1-Ethenylbenzene. 2. Properties. Macromolecules, 29, 13891398. https://doi.org/10.1021/ma951150a

[56] Jacob, S., Manjusri, M. and Amar, K.M. (2013) Green Synthesis for Lignin Plasticization: Aqueous Graft Copolymerization with Methyl Methacrylate. Journal of Renewable Materials, in press.

[57] Mai, C., Majcherczyk, A. and Hüttermann, A. (2000) Chemo-Enzymatic Synthesis and Characterization of Graft Copolymers from Lignin and Acrylic Compounds. Enzyme and Microbial Technology, 27, 167-175. https://doi.org/10.1016/S0141-0229(00)00214-3

[58] Wang, J., Yao, K., Korich, A.L., Li, S., Ma, S., Ploehn, H.J., Iovine, P.M., Wang, C., Chu, F. and Tang, C. (2011) Combining Renewable Gum Rosin and Lignin: Towards Hydrophobic Polymer Composites by Controlled Polymerization. Journal of Polymer Science Part A: Polymer Chemistry, 49, 3728-3738. https://doi.org/10.1002/pola.24809

[59] Zhang, C.-Q., Wu, H.-C. and Kessler, M.-R. (2015) High Bio-Content Polyurethane Composites with Urethane Modified Lignin as Filler. Polymer, 69, 52-57. https://doi.org/10.1016/j.polymer.2015.05.046

[60] Yue, X.-P., Chen, F.-G. and Zhou, X.-S. (2011) Improved Interfacial Bonding of PVC/Wood-Flour Composites by Lignin Amine Modification. BioResources, 6, 2022-2034.

[61] Yeo, J.-S., Seong, D.-W. and Hwang, S.-H. (2015) Chemical Surface Modification of Lignin Particle and Its Application as Filler in the Polypropylene Composites. Journal of Industrial and Engineering Chemistry, 31, 80-85. https://doi.org/10.1016/j.jiec.2015.06.010

[62] Jin, Y., Cheng, X. and Zheng, Z. (2010) Preparation and Characterization of Phenol-Formaldehyde Adhesives Modified with Enzymatic Hydrolysis Lignin. Bioresource Technology, 101, 2046-2048. https://doi.org/10.1016/j.biortech.2009.09.085

[63] Ferdosian, F., Pan, Z., Gao, G. and Zhao, B. (2017) Bio-Based Adhesives and Evaluation for Wood Composites Application. Polymers, 9, 70. https://doi.org/10.3390/polym9020070

[64] Yang, S., Zhang, Y., Yuan, T.-Q. and Sun, R.-C. (2015) Lignin-Phenol-Formaldehyde Resin Adhesives Prepared with Biorefinery Technical Lignins. Journal of Applied Polymer Science, 132, 1-8. https://doi.org/10.1002/app.42493

[65] Vfizquez, G., Gonzfilez, J., Freire, S. and Antorrena, G. (1997) Effect of Chemical Modification of Lignin on the Gluebond Performance of Lignin-Phenolic Resins. Bioresource Technology, 60, 191-198. https://doi.org/10.1016/S0960-8524(97)00030-8

[66] Wang, M., Leitch, M. and Xu, C.-C. (2009) Synthesis of Phenol-Formaldehyde Resol Resins Using Organosolv Pine Lignins. European Polymer Journal, 45, 3380 - 
3388. https://doi.org/10.1016/j.eurpolymj.2009.10.003

[67] Guo, Z., Liu, Z., Ye, L., Ge, K. and Zhao, T. (2015) The Production of Lignin-Phenol-Formaldehyde Resin Derived Carbon Fibers Stabilized by BN Preceramic Polymer. Materials Letters, 142, 49-51.

https://doi.org/10.1016/j.matlet.2014.11.068

[68] Newman, W.H. and Glasser, W.G. (1985) Engineering plastics from lignin XII. Synthesis and Performance of Lignin Adhesives with Isocyanate and Melamine. Holzforschung, 39, 345-353. https://doi.org/10.1515/hfsg.1985.39.6.345

[69] Ma, Y., Zhao, X., Chen, X. and Wang, Z. (2011) An Approach to Improve the Application of Acid-Insoluble Lignin from Rice Hull in Phenol-Formaldehyde Resin. Colloids and Surfaces A: Physicochemical and Engineering Aspects, 377, 284-289. https://doi.org/10.1016/j.colsurfa.2011.01.006

[70] DonmezCavdar, A., Kalaycioglu, H. and Hiziroglu, S. (2008) Some of the Properties of Oriented Strandboard Manufactured Using Kraft Lignin Phenolic Resin. Journal of Materials Processing Technology, 202, 559-563. https://doi.org/10.1016/j.jmatprotec.2007.10.039

[71] Dongre, P., Driscoll, M., Amidon, T. and Bujanovic, B. (2015) Lignin-Furfural Based Adhesives. Energies, 8, 7897-7914. https://doi.org/10.3390/en8087897

[72] Foyer, G., Chanfi, B.H., Boutevin, B., Caillol, S. and David, G. (2016) New Method for the Synthesis of Formaldehyde-Free Phenolic Resins from Lignin-Based Aldehyde Precursors. European Polymer Journal, 74, 296-309. https://doi.org/10.1016/j.eurpolymj.2015.11.036

[73] Zhao, S. and Abuomar, M.M. (2017) Synthesis of Renewable Thermoset Polymers through Successive Lignin Modification Using Lignin-Derived Phenols. ACS Sustainable Chemistry \& Engineering, 5, 5059-5066. https://doi.org/10.1021/acssuschemeng.7b00440

[74] Zhao, S. and Abu-Omar, M.M. (2015) Biobased Epoxy Nanocomposites Derived from Lignin-Based Monomers. Biomacromolecules, 16, 2025-2031. https://doi.org/10.1021/acs.biomac.5b00670

[75] Zhao, S. and Abu-Omar, M.M. (2016) Renewable Epoxy Networks Derived from Lignin-Based Monomers: Effect of Cross-Linking Density. ACS Sustainable Chemistry \& Engineering, 4, 6082-6089. https://doi.org/10.1021/acssuschemeng.6b01446

[76] Yin, Q., Yang, W., Sun, C. and Di, M. (2012) Preparation and Properties of Lignin-Epoxy Resin Composite. BioResources, 7, 5737-5748. https://doi.org/10.15376/biores.7.4.5737-5748

[77] El Mansouri, N.E., Yuan, Q. and Huang, F. (2011) Synthesis and Characterization of Kraft Lignin-Based Epoxy Resins. BioResources, 6, 2492-2503.

[78] Xue, B.L., Wen, J.L. and Sun, R.C. (2014) Lignin-Based Rigid Polyurethane foam Reinforced with Pulp Fiber: Synthesis and Characterization. ACS Sustainable Chemistry \& Engineering, 2, 1474-1480. https://doi.org/10.1021/sc5001226

[79] Buono, P., Duval, A., Averous, L. and Habibi, Y. (2017) Lignin-Based Materials through Thiol-Maleimide "Click" Polymerization. ChemSusChem, 10, 984-992. https://doi.org/10.1002/cssc.201601738

[80] Mao, C.P. and Wu, S.B. (2014) Adsorption of Polyvinyl Acetate (PVAc) Adhesive Emulsion from Aqueous Solution by Lignin-Phenol Based Cationic Surfactant Modified Organic Kieselguhr. Applied Mechanics and Materials, 472, 861-866. https://doi.org/10.4028/www.scientific.net/AMM.472.861

[81] Zhang, W., Ma, Y., Xu, Y., Wang, C. and Chu, F. (2013) Lignocellulosic Ethanol Re- 
sidue-Based Lignin-Phenol-Formaldehyde Resin Adhesive. International Journal of Adhesion and Adhesives, 40, 11-18. https://doi.org/10.1016/j.ijadhadh.2012.08.004

[82] Nacas, A.M., Ito, N.M., Sousa, R.R.D., Spinacé, M.A. and Dos Santos, D.J. (2017) Effects of NCO: OH Ratio on the Mechanical Properties and Chemical Structure of Kraft Lignin-Based Polyurethane Adhesive. The Journal of Adhesion, 93, 18-29. https://doi.org/10.1080/00218464.2016.1177793 